\title{
PLS-SEM Analysis to Know Factors Affecting The Interest of Buying Halal Food in Muslim Students
}

\author{
Cindy Cahyaning Astuti ${ }^{1}$ \\ ${ }^{1}$ Information Technology Education, Universitas Muhammadiyah Sidoarjo, Indonesia, e-mail : \\ cindy.cahyaning@umsida.ac.id
}

Article history:

Received : 29-03-2021

Reviced : 14-04-2021

Accepted : 16-04-2021

\section{Keyword:}

Halal Food;

Muslim Student;

PLS-SEM

\section{ABSTRACT}

The increase of halal food products has led to increase in culinary tourism in recent years. One of the districts that has experienced a rapid increase in culinary tourism is Sidoarjo Regency. The development of culinary tourism in the last few years in Sidoarjo Regency generally targets are the students. This study will aim to determine the factors that influence the interest in buying halal food and what factors have the greatest influence on the interest in buying halal food. The analysis technique uses the Partial Least Squares Structural Equation Modeling (PLS-SEM. Based on the results of the analysis, it is known that of the 5 predictor variables used in the analysis process, there are 4 variables that have a significant effect on Purchase Interest (Y). It can be concluded that increasing of Halal Awareness (X1), Halal Certification (X2), Health (X3) and Value Perception (X5) will further increase Purchase Interest (Y). Meanwhile, based on value of coefficient on each variable, it is known that Health (X3) has the largest coefficient value $(0.260)$, so it can be concluded that Health (X3) has the greatest influence on Purchase Interest (Y).

This is an open access article under the CC BY-SA license.

DOI: https://doi.org/10.30812/varian.v4i2.1141

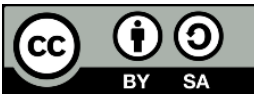

\section{A. INTRODUCTION}

Islam is religion that regulates everything related to life of its adherents. All kinds of things are considered both in terms of benefits and harms, including those related to food. Food is a meaningful thing for the continuity of human life (Ali, 2016). Food provides energy for humans so that humans can carry out activities. For that in Islam we know the terms halal and haram food. Indonesia is one of the countries with the largest Muslim population in the world, this has led to an increase in demand for processed halal food products. The increase in demand for processed halal food products has led to an increase in culinary tourism destinations in recent years, both in big cities and small cities in Indonesia. One of the districts that has experienced a rapid increase in culinary tourism is Sidoarjo Regency. The rapid development of culinary tourism in the last few years in Sidoarjo Regency generally targets the student target market. Majority of students being Muslim in Sidoarjo Regency, consuming halal food is a huge market potential. Several culinary tours in Sidoarjo Regency have implemented the concept of halal tourism. With the concept of halal tourism, culinary tourism in Sidoarjo Regency needs to introduce halal culinary tourism as well. However, the interest of Muslim students in buying halal food has never been measured.

Halal food is defined as something that is allowed by the Shari'ah to be consumed unless there is a prohibition from Allah SWT and Prophet Muhammad SAW (Listyoningrum \& Albari, 2012). However, the procedures and standards of halalness are not limited to following the written teachings. There is also supervision in terms of cleanliness and quality. Starting from the raw materials and equipment used must comply with sharia law and meet the requirements. The food production process needs to be monitored and 
supervised by competent Muslim supervisor. The behavior of a product depends on the consumer's interest in buying. Interest is consumer interest in a product (Nurrachmi, 2017). Someone who has a positive attitude towards a product will have an interest in buying that product (Nulufi \& Murwartiningsih, 2015). Several previous studies on halal food stated that the variables of halal awareness, health and perceived value had a significant positive effect on buying interest in halal processed food products (Nurhasanah et al., 2017). In addition, other research states that the variables of halal certification, product ingredients and purchase intention have a significant effect on purchasing decisions (Yuwono, 2017). Based on this, this research will focus on knowing what factors influence the interest in buying halal food and which factors have the greatest influence on the interest in buying halal food in Muslim students in Sidoarjo Regency. While the analysis technique used Partial Least Square Structural Equation Modeling (PLS-SEM) analysis.

\section{B. LITERATURE REVIEW}

\section{Halal Culinary Tourism}

Halal culinary tourism has experienced a high increase in recent years, this is because we are in an Indonesian country which has a majority Muslim population. The existence of halal culinary tourism has a positive effect on the selection of Halal tourist destinations (Komalasari et al., 2020). One area that has experienced an increase in halal culinary tourism destinations is Sidoarjo Regency. In general, the target market for halal culinary tourism in Sidoarjo Regency is Muslim students, so knowing the characteristics of Muslim students as consumers of halal culinary tourism is considered very important. Consuming halal food is an obligation for every Muslim (Soon et al., 2017). Halal can be defined as something that is allowed or often refers to food that is allowed for Muslims. Certification is an important aspect that must be completed by owners of halal culinary tours, because it is one of the factors that can increase consumer buying interest (Aniqoh \& Hanastiana, 2020). The Halal certificate is issued by the Indonesian Ulema Council (MUI) after certain tests and analyzes carried out by the Indonesian Ulema Council (LPPOM MUI) Food, Drug and Cosmetics Assessment Institute (LPPOM MUI) to see whether the product meets the requirements set by LPPOM MUI (Setyaningsih \& Marwansyah, 2019) .

The marketing of a food processed product depends on the consumer's interest in buying. Product marketing has an effect on consumer buying interest (Anggriani et al., 2020). Purchase interest can be defined as consumer interest in a product. Someone who has an interest in a product will arise an interest in buying that product. Another factor that can influence consumer behavior in buying or choosing a product is based on experience in using or consuming a product. Several other variables, namely health, halal awareness and perceived value in previous research on halal food, stated that these variables have a significant positive effect on buying interest in halal processed food products)(Peristiwo, 2019). The results of the study (Sufi Fauzia et al., 2019) show that the variables of halal certification, product ingredients and purchase intention have a significant effect on purchasing decisions. Furthermore, research (Shahnaz \& Wahyono, 2016) shows that reputation and trust variables have a positive and significant effect on purchase intention. In addition, other research results show that the variables of halal certification, food ingredients and purchase intention have a significant effect on purchasing decisions (Nafis, 2019). This study aims to classify the characteristics of Muslim students as consumers of halal culinary tourism in Sidoarjo Regency. There are several factors used in the classification process, including halal awareness, halal certification, health, food ingredients, perceived value and interest in buying halal food.

\section{Partial Least Square Structural Equation Modeling (PLS-SEM)}

In this study, the data analysis technique used Partial Least Square Structural Equation Modeling (PLSSEM) with the SmartPLS 3.0 program. The advantage of PLS SEM analysis is able to map all paths in structural model to all response variable, in same research model as well as to analyze all paths in the structural model simultaneously. The PLS SEM analysis also does not require multivariate normal assumptions. In the PLS SEM structural model, the predictor variables can be reflective and formative. The initial stage was the measurement of the reflective model. There are 4 stages of inspection, namely Internal Consistency Reliability (using CR), Reliability Indicator (using Outer Loading), Convergent Validity (using 
AVE) and Discriminant Validity (using the Former Larcker Criterion). Internal consistency reliability can be measured by composite reliability (CR). In order to meet the criteria, the CR value must be greater than 0.7 . The reliability indicator can be measured by looking at the outer loading value, if outer loading $>0.7$ then the indicator is used. If there is an outer loading between 0.4 to 0.7 then it needs to be rerun to see the effect of removing indicators on AVE and CR (if AVE and CR increase above the threshold then indicators with outer loading between 0.4 to 0.7 need to be removed, otherwise it remains used). If outer loading $<0.4$ then the indicator is discarded. Convergent validity value can be measured using AVE. If the AVE value is $>0.5$, the criteria for convergent validity are met. Discriminant Validity can be measured using the Fornell-Larcker Criterion. A latent variable shares more variance with the underlying indicator than with other latent variables. This is what underlies the Fornell-Larcker Criterion. The root value of AVE (diagonal matrix) must be greater than all values both to the left and down (Hair et al, 2017).

The second stage is a formative examination. There are two stages, namely collinearity issues which can be checked using the Outer VIF value and the Significant Outer Weight which can be seen from the P-Value. The Outer VIF value must be less than 5 while the Outer Weight P-value must be less than 0.05 to be concluded as significant. After the examination of the outer model is complete, it is followed by an assessment of the measurement results of the structural model (inner model). There are 5 stages, namely Collinierity Assessment (using VIF), Structural Model Path Coefficients (using the test), Coefficient of Determination (using R2), Effect Size (using f2) and Predictive Relevance (using Q2). Structural model coefficient analysis is used to determine which relationship has a significant effect. If the $p$-value $<\alpha(0.05)$ then the relationship is significant, conversely if the $p$-value $\geq \alpha(0.05)$ then the relationship is not significant. The coefficient of determination is used to measure the accuracy of the estimation. In addition to evaluating the $\mathrm{R} 2$ value of all endogenous variables we can use $\mathrm{f} 2$. The difference between $\mathrm{f} 2$ and $\mathrm{R} 2$ is that f2 is more specific for each exogenous variable. In addition to evaluating the value of R2 as a criterion for predictive accuracy, researchers can use the Stone-Geissers Q2 value. The value of Q2 was obtained using a blindfolding procedure. As a relative measure of predictive relevance, a value of 0.02 is considered to have small predictive relevance, 0.15 has moderate predictive relevance and 0.35 has large predictive relevance (Hair et al., 2017). The structural equation modeling (SEM) and Partial Least Square (PLS) notation used in this study can be seen in Figure 1 as follows:

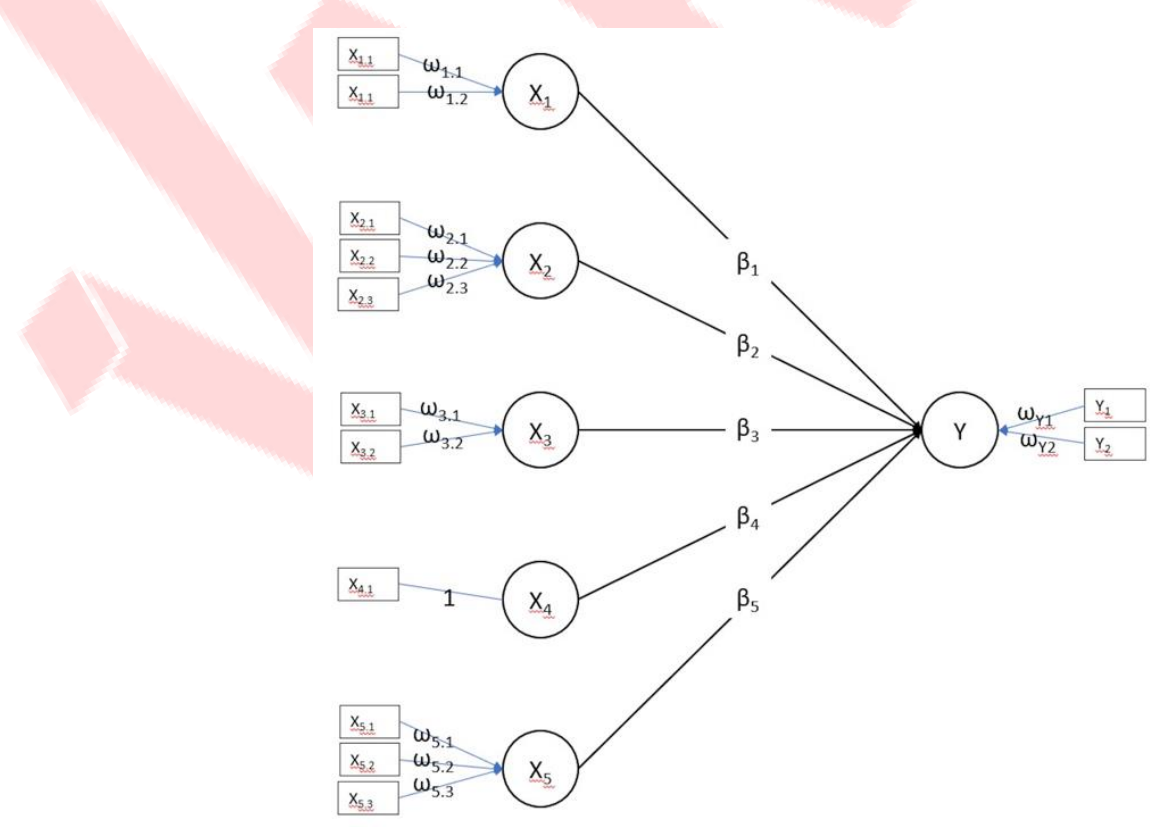

Figure 1. Partial Least Square (PLS) Notation 
Where the notation used is:

$\begin{array}{ll}\mathrm{X} & =\text { Predictors Variables } \\ \mathrm{Y} & =\text { Response Variable } \\ \omega_{\mathrm{x}} & =\text { Loading Factors Predictor Latent Variables } \\ \omega_{\mathrm{y}} & =\text { Loading Factors Response Latent Variables } \\ \beta & =\text { Coefficient of influence predictor variables on the response variable }\end{array}$

Partial Least Square Structural Equation Modeling in its mathematical equation in this study can be seen in equation 1 as follows:

$$
Y=\beta_{1} X_{1}+\beta_{2} X_{2}+\beta_{3} X_{3}+\beta_{4} X_{4}+\beta_{5} X_{5}
$$

Mathematical equations that are formed based on the number of predictor variables used

\section{RESEARCH METHODS}

In this research, data analysis technique using Partial Least Square Structural Equation Modeling (PLSSEM). The analysis process using the PLS-SEM technique consisted of 3 stages. The first is the measurement of the reflective model (Outer Model), the second is the measurement of the formative model (Outer Model) and the third is the measurement of the structural model (Inner Model). The analysis process for the three stages was carried out with the SmartPLS 3.0 program. The PLS-SEM analysis flow chart in this study is presented in Figure 2 as follows:

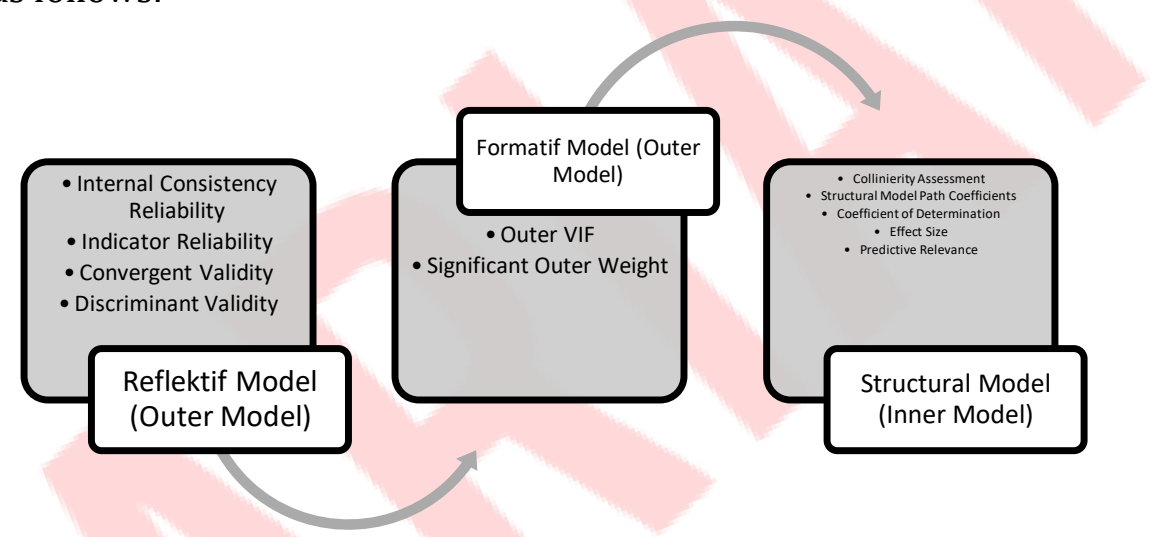

Figure 2. The Stages of PLS-SEM Analysis

The initial stage is the measurement of the reflective model. There are 4 stages of inspection, some of the steps in initial stage are as follows:

a. Internal Consistency Reliability (using CR);

b. Reliability Indicator (using Outer Loading);

c. Convergent Validity (using AVE);

d. Discriminant Validity (using the Former Larcker Criterion).

The second stage is a formative examination. There are two stages, some of the steps in second stage are as follow:

a. Outer VIF value;

b. Significant Outer Weight which can be seen from the P-Value.

The Outer VIF value must be less than 5 while the Outer Weight P-value must be less than 0.05 to be concluded as significant.

After the examination of the outer model is complete, it is followed by an assessment of the measurement results of the structural model (inner model). There are 5 stages, some of the steps in inner model stage are as follows:

a. Collinierity Assessment (using VIF);

b. Structural Model Path Coefficients (using the $t$ test);

c. Coefficient of Determination (using R2); 
d. Effect Size (using f2);

e. Predictive Relevance (using Q2).

The descriptions of the research variables are presented in Table 1 as follows:

Table 1. Research Variables

\begin{tabular}{|c|c|c|}
\hline Variable & Indicator & Statement \\
\hline Halal Awareness (X1) & $\begin{array}{l}\text { 1. Knowledge of halal food } \\
\text { (X1.1) }\end{array}$ & I know the food I eat is halal \\
\hline & $\begin{array}{l}\text { 2. Belief in the process of } \\
\text { cooking food in accordance } \\
\text { with the provisions of the } \\
\text { Shari'a (X1.2) }\end{array}$ & $\begin{array}{l}\text { I believe that the food I eat is } \\
\text { cooked according to the } \\
\text { provisions of the Shari'a }\end{array}$ \\
\hline Halal Certific & $\begin{array}{l}\text { 1. Knowledge of halal } \\
\text { certificates in culinary places } \\
(\mathrm{X} 2.1)\end{array}$ & $\begin{array}{l}\text { I know that LPPOM MUI can } \\
\text { provide halal certification to } \\
\text { culinary places that have met the } \\
\text { requirements }\end{array}$ \\
\hline & $\begin{array}{l}\text { 2. Availability of halal } \\
\text { certificates at culinary places } \\
(\mathrm{X} 2.2)\end{array}$ & $\begin{array}{l}\text { I know that the culinary places I } \\
\text { visited have halal certificates }\end{array}$ \\
\hline & $\begin{array}{l}\text { 3. Importance of halal } \\
\text { certification }(\mathrm{X} 2.3)\end{array}$ & $\begin{array}{l}\text { I feel that halal certification is } \\
\text { important in culinary places }\end{array}$ \\
\hline Health (X3) & $\begin{array}{l}\text { 1. Eating halal food is healthy } \\
\text { (X3.1) }\end{array}$ & $\begin{array}{l}\text { I believe that eating halal food is } \\
\text { healthy }\end{array}$ \\
\hline & $\begin{array}{l}\text { 2. Eating halal food can prevent } \\
\text { disease (X3.2) }\end{array}$ & $\begin{array}{l}\text { I believe that eating halal food } \\
\text { can prevent disease }\end{array}$ \\
\hline Food Ingredients (X4) & $\begin{array}{l}\text { 1. The halal ingredients of the } \\
\text { food used (X4.1) }\end{array}$ & $\begin{array}{l}\text { I know the food ingredients from } \\
\text { the food I eat are halal }\end{array}$ \\
\hline Value Perception (X5) & $\begin{array}{l}\text { 1. The suitability of price with } \\
\text { the taste of food (X5.1) }\end{array}$ & $\begin{array}{l}\text { The prices at the culinary places I } \\
\text { visited match the taste served }\end{array}$ \\
\hline & $\begin{array}{l}\text { 2. Price compatibility with } \\
\text { convenience in culinary } \\
\text { places (X5.2) }\end{array}$ & $\begin{array}{l}\text { The prices at the culinary places I } \\
\text { visited are in accordance with the } \\
\text { comfort of the environment in the } \\
\text { culinary places }\end{array}$ \\
\hline & $\begin{array}{l}\text { 3. The suitability of prices with } \\
\text { services in culinary places } \\
\text { (X5.3) }\end{array}$ & $\begin{array}{l}\text { The price at the culinary place } \\
\text { that I visited is in accordance } \\
\text { with the service at the culinary } \\
\text { place }\end{array}$ \\
\hline Purchase Interest (Y) & $\begin{array}{l}\text { 1. Interest in buying halal food } \\
\text { (Y1.1) }\end{array}$ & $\begin{array}{l}\text { I am interested in buying halal } \\
\text { food }\end{array}$ \\
\hline & $\begin{array}{l}\text { 2. Recommend halal food to } \\
\text { others (Y1.2) }\end{array}$ & I recommend halal food to others \\
\hline
\end{tabular}

\section{RESULTS AND DISCUSSION}

\section{Reflective Measurement Model}

The initial stage is the measurement of the reflective model. The measurement of the refractory model is carried out on variables that have reflective indicators. In this study, reflective indicators are found in Health (X3) and Purchase Interest (Y). The stages of measuring the reflective model consist of 4 stages of inspection, namely Internal Consistency Reliability using the CR value, Indicator Reliability using the Outer Loading value, Convergent Validity using the AVE value and Discriminant Validity using the Former Larcker Criterion value. 
a. Internal Consistency Reliability

Internal consistency reliability can be measured by Composite Reliability (CR). In order to meet the criteria, the CR value must be greater than 0.7 . Based on the results of the analysis, the composite reliability (CR) value for Health (X3) and Purchase Interest (Y) is as table 2 :

Table 2. Value of Composite Reliability

\begin{tabular}{cc}
\hline Variable & $\begin{array}{c}\text { Composite Reliability } \\
\text { (CR) }\end{array}$ \\
\hline Health & 0.931 \\
\hline Purchase Interest & 0.930 \\
\hline
\end{tabular}

Based on Table 2, it is known that of the 2 variables that have refractory indicators, namely Health (X3) and Purchase Interest (Y), both of them have a CR value greater than 0.7. So it can be said that the two variables are reliable and can be used in the next analysis process.

b. Reliability indicator

The reliability indicator can be measured by looking at the outer loading value, if outer loading $>0.7$ then the indicator is used. If there is an outer loading between 0.4 to 0.7 then it needs to be rerun to see the effect of removing indicators on AVE and CR (if AVE and CR increase above the threshold then indicators with outer loading between 0.4 to 0.7 need to be removed, otherwise it remains used). If outer loading $<0.4$ then the indicator is discarded. Based on the results of the analysis, it is obtained the outer loading value of each indicator for the 2 variables as table 3 :

Table 3. Outer Loading Results

\begin{tabular}{ccc}
\hline \multirow{2}{*}{ Indicator } & \multicolumn{2}{c}{ Outer Loading } \\
\cline { 2 - 3 } & Health & $\begin{array}{c}\text { Purchase } \\
\text { Interest }\end{array}$ \\
\hline X3.1 & 0.941 & \\
\hline X3.2 & 0.926 & 0.956 \\
\hline Y1.1 & 0.908 \\
\hline Y1.2
\end{tabular}

Based on Table 3, it is known that all reflective indicators on Health (X3) and Purchase Interest (Y) have an outer loading value above 0.7 . So it can be said that all reflective indicators are reliable to measure Health (X3) and Purchase Interest (Y).

c. Convergent Validity

The value of Convergent validity can be measured using the Average Variance Extracted (AVE) value. If the AVE value is greater than 0.5, the convergent validity criteria are met. Based on the results of the analysis, the AVE values of the variables were obtained as table 4:

Table 4. Value of AVE

\begin{tabular}{cc}
\hline Variable & Average Variance Extracted (AVE) \\
\hline Health & 0.872 \\
\hline Purchase Interest & 0.870 \\
\hline
\end{tabular}

Based on Table 4, it is known that the AVE value of Health (X3) and Purchase Interest (Y) exceeds 0.5 so that it can be said that the two variables are valid. 


\section{d. Discriminant Validity}

Discriminant Validity can be measured using the Fornell-Larcker Criterion value. A latent variable shares more variance with the underlying indicator than with other latent variables, which underlies the FornellLarcker Criterion. The root AVE (diagonal matrix) value must be greater than all values either to the left or down. Based on the results of the analysis, the Fornell-Larcker Criterion value for Health (X3) and Purchase Interest $(\mathrm{Y})$ is obtained as table 5 and table 6 :

Table 5. Discriminant Validity of Health (X3)

\begin{tabular}{ccccccc}
\hline Variabel & X4 & X1 & X3 & Y & X5 & X2 \\
\hline X4 & 1.000 & & & & & \\
\hline X1 & 0.373 & & & & \\
\hline X3 & 0.390 & 0.469 & 0.934 & & \\
\hline Y & 0.298 & 0.440 & 0.475 & 0.933 & \\
\hline X5 & 0.500 & 0.413 & 0.399 & 0.384 & \\
\hline X2 & 0.417 & 0.425 & 0.457 & 0.414 & 0.434 \\
\hline
\end{tabular}

Table 6. Discriminant Validity of Purchase Interest (Y)

\begin{tabular}{ccccccc}
\hline Variabel & X4 & X1 & X3 & Y & X5 & X2 \\
\hline X4 & 1.000 & & & & \\
\hline X1 & 0.373 & & & & \\
\hline X3 & 0.390 & 0.469 & 0.934 & & \\
\hline Y & 0.298 & 0.440 & 0.475 & 0.933 & \\
\hline X5 & 0.500 & 0.413 & 0.399 & 0.384 & \\
\hline X2 & 0.417 & 0.425 & 0.457 & 0.414 & 0.434 \\
\hline
\end{tabular}

Based on Table 5, it is known that for Health (X3) the root value of AVE is higher than the correlation of health with other variables so that the health measurement indicators are valid. Meanwhile, based on Table 6, it is known that for the purchase interest variable, the root of AVE is also higher than the correlation of buying interest with other variables so that the measuring indicator of buying interest can be said to have been valid.

\section{Formative Model Measurement}

The second stage is the measurement of the formative model. Measurement of the formative model is carried out on variables that have formative indicators. In this study, the formative indicators are found in the variables of Halal Awareness (X1), Halal Certification (X2) and Value Perception (X5). Meanwhile, Food Ingredients (X4) is a variable with one indicator (single construct) so that there is no need to measure a reflective model or measure a formative model. The measurement stage for the formative model consists of two steps, namely the Collinearity Issue which is carried out using the Outer VIF value and the Significant Outer Weight which is carried out using the P-Value value.

a. Collinearity Issue

Collinearity Issue is measured using the Outer VIF value. The Outer VIF value for each formative indicator must be less than 5 . Based on the analysis results, the Outer VIF value is as table 7:

Table 7. VIF Value on Formative Indicators

\begin{tabular}{ccc}
\hline Variable & Indicator & VIF \\
\hline \multirow{2}{*}{ X1 } & $\mathrm{X} 1.1$ & 1.885 \\
\cline { 2 - 3 } & $\mathrm{X} 1.2$ & 1.885 \\
\hline $\mathrm{X} 2$ & $\mathrm{X} 2.1$ & 2.370 \\
\hline
\end{tabular}




\begin{tabular}{ccc}
\hline Variable & Indicator & VIF \\
\hline \multirow{2}{*}{ X5 } & $\mathrm{X} 2.2$ & 1.847 \\
\cline { 2 - 3 } & $\mathrm{X} 2.3$ & 1.836 \\
\hline & $\mathrm{X} 5.1$ & 3.022 \\
\cline { 2 - 3 } & $\mathrm{X} 5.2$ & 2.178 \\
\cline { 2 - 3 } & $\mathrm{X} 5.3$ & 2.221 \\
\hline
\end{tabular}

Based on Table 7, it is known that the Outer VIF value on formative indicators has a value below 5 for all formative indicators on the three variables of Halal Awareness (X1), Halal Certification (X2) and Value Perception (X5). So it can be said that there is no indication of multicollinearity in each formative indicator for all the variables used.

b. Significant Outer Weight

The significant Outer Weight can be seen using the p-value. The value of the Significant Outer Weight must be less than 0.05 in order to say that the formative indicator is significant and usable. Based on the results of the analysis, the p-value for each formative indicator is as table 8:

Table 8. P-Value of Formative Indicators

\begin{tabular}{lr}
\hline Indikator -> Variabel & P Values \\
\hline X1.1 -> Halal Awareness & 0.000 \\
\hline X1.2 -> Halal Awareness & 0.656 \\
\hline X2.1 -> Halal Certification & 0.002 \\
\hline X2.2 -> Halal Certification & 0.080 \\
\hline X2.3 -> Halal Certification & 0.008 \\
\hline X5.1 -> Value Perception & 0.016 \\
\hline X5.2 -> Value Perception & 0.793 \\
\hline X5.3 -> Value Perception & 0.005 \\
\hline
\end{tabular}

Based on Table 8, it is known that there is a p-value for formative indicators that is not significant, namely a p-value greater than 0.05 , these indicators include indicators X1.2, X2.2 and X5.2. So that the three indicators need to be tested further by checking outer loading. Whereas for the indicators X1.1, X2.1, X2.3, $\mathrm{X} 5.1$ and X5.3, it is significant with a p-value that is smaller than 0.05 , so that the indicator is feasible to use. Next, an inspection of the outer loading indicators X1.2, X2.2 and X5.2 is performed which is presented in Table 9 as follows:

Table 9. Outer Loading Results and P-Value Outer Loading Formative Indicators

\begin{tabular}{ccc}
\hline Indikator -> Variabel & Outer Loading & P Values \\
\hline X1.2 -> Halal Awareness & 0.718 & 0.000 \\
\hline X2.2 -> Halal Awareness & 0.793 & 0.000 \\
\hline X5.2 -> Value Perception & 0.737 & 0.000 \\
\hline
\end{tabular}

Based on Table 9, it is known that the outer loading value for the X1.2, X2.2 and X5.2 indicators has a value above 0.5 . So it can be said that the X1.2, X2.2 and X5.2 indicators are still feasible to use.

\section{Measurement of the Structural Model (Inner Model)}

Furthermore, after the examination of the outer model is complete, it is followed by an assessment of the measurement results of the structural model (inner model). There are 5 stages in the measurement of the structural model (inner model), namely Collinierity Assessment using the VIF value, Structural Model Path Coefficients using the $t$ test, Coefficient of Determination using the R2 value, Effect Size using the f2 value and Predictive Relevance using the Q2 value. 
Structural model coefficient analysis is used to determine which relationship between variables has a significant effect. The results of the structural model coefficient analysis (inner model) can be seen in Table 10. If the $p$-value $<\alpha(0.05)$ then the relationship between these variables is significant, conversely if the $p$ value $\geq \alpha(0.05)$ then the relationship between variables is insignificant. The coefficient of determination is used to measure the accuracy of the estimation. In addition to evaluating the R2 value of all endogenous variables we can use $\mathrm{f} 2$. The difference between $\mathrm{f} 2$ and $\mathrm{R} 2$ is that $\mathrm{f} 2$ is more specific for each exogenous variable. In addition to evaluating the value of R2 as a criterion for predictive accuracy, we can also use the Stone-Geissers Q2 value. The value of Q2 was obtained using a blindfolding procedure. As a relative measure of predictive relevance, value of 0.02 was considered to have little predictive relevance, 0.15 had moderate predictive relevance and 0.35 had large predictive relevance. The results of the structural model coefficient analysis (Inner Model) are presented in Figure 2 and Table 10 as follows:

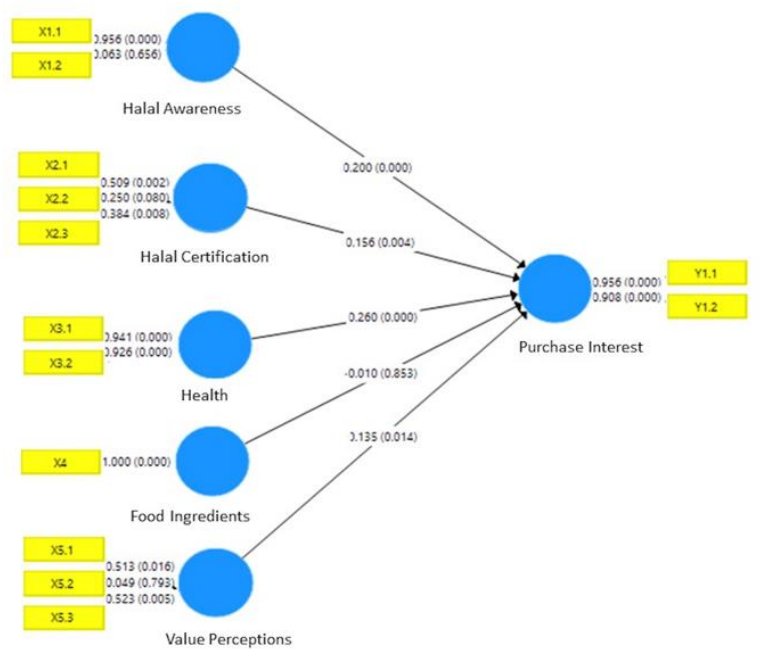

Figure 2. Structural Model Coefficient (Inner Model)

Table 10. Influence between Variables

\begin{tabular}{cccc} 
& \multicolumn{3}{c}{ Table 10. Influence between Variables } \\
\cline { 2 - 4 } & $\begin{array}{c}\text { Influence between } \\
\text { Variables }\end{array}$ & Coefficient & P Values \\
\hline $\mathrm{X} 1$ & 0.200 & 0.000 \\
\hline $\mathrm{X} 2$ & 0.156 & 0.004 \\
\hline $\mathrm{X} 3$ & 0.260 & 0.000 \\
\hline $\mathrm{X} 4$ & -0.010 & 0.853 \\
\hline $\mathrm{X} 5$ & 0.135 & 0.014 \\
\hline
\end{tabular}

Based on the results of the analysis using SEM PLS, the mathematical equations formed are as equation (2) :

$Y=0.200 X_{1}+0.156 X_{2}+0.260 X_{3}-0.010 X_{4}+0.135 X_{5}$

Based on equaton 2, Figure 2 and Table 10, it is known that Halal Awareness (X1) has a p-value of (0.000), Halal Certification (X2) has a p-value(0.004), Health (X3) has a p-value ( 0.000) and the Value Perception (X5) has p-value (0.0014). These four variables have a p-value smaller than $\alpha(0.05)$, so it can be said that the variables of Halal Awareness (X1), Halal Certification (X2), Health (X3) and Value Perception (X5) have a significant effect on Purchase Interest (Y). Meanwhile, Food Ingredients (X4) does not have a significant effect on Purchase Interest (Y). because it has a p-value (0.853) greater than $\alpha(0.05)$. So it can be concluded that the increasing of Halal Awareness (X1), Halal Certification (X2), Health (X3) and Value Perception (X5) will further increase Purchase Interest (Y). Meanwhile, based on the coefficient value on 
each variable, it is known that Health (X3) has the largest coefficient value (0.260), so it can be concluded that Health (X3) has the greatest influence on Purchase Interest $(Y)$.

\section{E. CONCLUSSION AND SUGGESTION}

Based on the results of the analysis of Partial Least Square Structural Equation Modeling (PLS SEM), it is known that of the 5 predictor variables used in the analysis process, namely Halal Awareness (X1), Halal Certification (X2), Health (X3), Food Ingredients (X4) and Based on the results of the analysis of Partial Least Square Structural Equation Modeling (PLS SEM), it is known that of the 5 predictor variables used in the analysis process, namely Halal Awareness (X1), Halal Certification (X2), Health (X3), Food Ingredients (X4) and Value Perception (X5) there are 4 variables that have a significant effect on Purchase Interest (Y). The four variables are Halal Awareness (X1), Halal Certification (X2), Health (X3) and Value Perception (X5). Meanwhile, Food Ingredients (X4) has no significant effect on Purchase Intention (Y). So it can be concluded that the increasing of Halal Awareness (X1), Halal Certification (X2), Health (X3) and Value Perception (X5) will further increase Purchase Interest (Y). Meanwhile, based on the coefficient value on each variable, it is known that Health (X3) has the largest coefficient value (0.260), so it can be concluded that Health (X3) has greatest influence on Purchase Interest (Y). Meanwhile, based on the coefficient value on each variable, it is known that Health (X3) has the largest coefficient value $(0.260)$, so it can be concluded that the Health variable (X3) has the greatest influence on Purchase Interest (Y). There are 4 variables that have a significant effect on Purchase Interest (Y). The four variables are Halal Awareness (X1), Halal Certification (X2), Health (X3) Value Perception (X5). Meanwhile, Food Ingredients (X4) has no significant effect on Purchase Interes (Y). So it can be concluded that the increasing of Halal Awareness (X1), Halal Certification (X2), Health (X3) and Value Perception (X5) will further increase Purchase Interest (Y). Meanwhile, based on the coefficient value on each variable, it is known that Health (X3) has the largest coefficient value $(0.260)$, so it can be concluded that Health (X3) has the greatest influence on Purchase Interest (Y). Meanwhile, based on the coefficient value on each variable, it is known that Health (X3) has the largest coefficient value (0.260), so it can be concluded that Health(X3) has the greatest influence on Purchase Interest (Y).

Suggestions that can be recommended based on the results are managers of halal culinary tourism to maintain and continue improve products while still paying attention to halal aspects which are reflected in variables of Halal Awareness (X1), Halal Certification (X2), Health (X3) Value Perception (X5) in order to continue increase buying interest. This research was conducted before the Covid 19 pandemic occurred, another recommendation that can be given is be able to conduct research related to the interest in buying halal food when the Covid 19 pandemic occurs until the new normal policy by implementing this health protocol, because thCovid 19 pandemic will certainly change perceptions and people's purchasing power for halal food.

\section{ACKNOWLEDGEMENT}

Thanks are addressed to the University of Muhammadiyah Sidoarjo. Do not forget to also thank Angga Dwi Mulyanto, M.Si., a lecturer at UIN Maulana Malik Ibrahim Malang who was willing to discuss a lot about PLS SEM.

\section{REFERENCES}

Ali, M. (2016). Konsep Makanan Halal dalam Tinjauan Syariah dan Tanggung Jawab Produk Atas Produsen Industri Halal. Ahkam: Jurnal Ilmu Syariah, http://journal.uinjkt.ac.id/index.php/ahkam/article/view/4459

Anggriani, R., Anggrawan, A., \& Cahyadi, I. (2020). Structural Analysis of the Equation Model on Store Atmosphere towards Hedonic Value and Consumer Impulsive Buying (Study at Majapahit Food Center). Jurnal Varian, 4(1), 61-70. https://doi.org/10.30812/varian.v4i1.851

Aniqoh, N. A. F. A., \& Hanastiana, M. R. (2020). Halal Food Industry: Challenges and Opportunities in Europe. Journal of Digital Marketing and Halal Industry, 2(1), 43. https://doi.org/10.21580/jdmhi.2020.2.1.5799

Hair, J. F., Hult, G. T. M., Ringle, C. M., \& Sarstedt, M. (2017). A Primer on Partial Least Squares Structural Equation Modeling (PLS-SEM) (Second Edi). Sage Publicatons. 
Komalasari, D., Hadijati, M., Fitriyani, N., \& Kurnia, A. (2020). Factor Extraction and Bicluster Analysis on Halal Destinations in Lombok Island. Jurnal Varian, 4(1), 1-10. https://doi.org/10.30812/varian.v4i1.743

Listyoningrum, A., \& Albari, A. (2012). Analisis Minat Beli Konsumen Muslim Terhadap Produk Yang Tidak Diperpanjang Sertifikat Halalnya. Jurnal Ekonomi Dan Keuangan Islam, 2(1), 40-51.

Nafis, M. C. (2019). The Concept of Halal and Thayyib and Its Implementation in Indonesia. Journal of Halal Product and Research, 2(1), 1. https://doi.org/10.20473/jhpr.vol.2-issue.1.1-5

Nulufi, K., \& Murwartiningsih, M. (2015). Minat Beli Sebagai Mediasi Pengaruh Brand Image Dan Sikap Konsumen Terhadap Keputusan Pembelian Batik DI Pekalongan. Management Analysis Journal, 4(2), 129-141. https://doi.org/10.15294/maj.v4i2.7813

Nurhasanah, S., Munandar, J. M., \& Syamsun, M. (2017). Faktor-Faktor yang Mempengaruhi Minat Beli Produk Makanan Olahan Halal pada Konsumen. Jurnal Manajemen Dan Organisasi, 8(3), 250-260. https://doi.org/10.29244/jmo.v8i3.22473

Nurrachmi, R. (2017). The Global Development of Halal Food Industry: A Survey Halal industry is the latest trend in the world market. Tazkia Islamic Finance and Business Review, 11(1), 41-56.

Peristiwo, H. (2019). Indonesian Halal Food Industry: Development, Opportunitie and Challenges on Halal Supply Chains. Journal of Islamic Studies and Humanities, 4(2), 218-245.

Setyaningsih, E. D., \& Marwansyah, S. (2019). The Effect of Halal Certification and Halal Awareness through Interest in Decisions on Buying Halal Food Products. Syi 'ar Iqtishadi : Journal of Islamic Economics, Finance and Banking, 3(1), 65. https://doi.org/10.35448/jiec.v3i1.5515

Shahnaz, N. B. F., \& Wahyono, W. (2016). Faktor yang Mempengaruhi Minat Beli Konsumen di Toko Online. Management Analysis Journal, 5(4). https://doi.org/10.15294/maj.v5i4.5571

Soon, J. M., Chandia, M., \& Regenstein, J. Mac. (2017). Halal integrity in the food supply chain. British Food Journal, 119(1), 39-51. https://doi.org/10.1108/BFJ-04-2016-0150

Sufi Fauzia, D. R., Pangestuti, E., \& Bafadhal, A. S. (2019). Pengaruh Religuitas, Sertfikasi Halal, Bahan Produk Terhadap Minat Beli Dan Keputusan Pembelian. Jurnal Administrasi Bisnis, 66(1), 37-46.

Yuwono, D. B. (2017). Kepedulian Muslim Perkotaan Terhadap Kehalalan Makanan Produk Pengusaha Mikro Kecil (Kasus pada Masyarakat Muslim Minoritas di Kota Kupang, NTT) ). Panangkaran: Jurnal Penelitian Agama Dan Masyarakat, 1(1), 111-137. https://doi.org/10.14421/panangkaran.2017.0101-07 
152 | Jurnal Varian| Vol.4, No.2, April 2021, Hal. 141-152 